\title{
Assessment of the Attractiveness of Foreign Markets - A Case Study. Comparison of Armenia and Poland
}

\author{
Andranik Muradyan \\ University of Warsaw, Faculty of Management \\ E-mail: murand190294@gmail.com
}

Received: 30 August 2018/ Revised: 22 October 2018/ Accepted: 25 October 2018/ Published online: 10 December 2018

\begin{abstract}
From the international marketing point of view, it is important to assess the attractiveness of the target country that can be interesting to foreign investors. It is worth analyzing all the possible opportunities and threats that may arise in each geographic market. It is also needed to assess the country's strengths and weaknesses and understand how these characteristic features can affect the company's growth perspectives. Each country has a specific political environment, sociodemographic features, economic situation, technological conditions, cultural identity, unique natural environment and legal rules. At the same time, there are regional and global geopolitical tendencies, common political structures, common economic conventions and elements of global culture. The specificity of the above-mentioned factors shapes a unique business environment that affects marketing strategies of entities that are planning to internationalize.

This article will present a proposal of several criteria for assessing the attractiveness of foreign markets. These criteria will be selected because of their reliability and acceptability by various global institutions. This method can be used to estimate attractiveness of every country, but only two of them have been chosen for this article. Based on these indicators, the attractiveness of the Armenian market will be compared to Poland's attractiveness. The example of Poland in some areas because of its increasing attractiveness may be useful for Armenia and its government
\end{abstract}

JEL classification: M31, F21, G11, F62

Keywords: evaluation of foreign markets, assessment criteria, Armenia, geopolitical and economic problems, avoiding barriers.

\section{INTRODUCTION}

Tense relations of the EU and the USA with Russia and Iran have negatively affected activities of business entities based in those countries. Mutual sanctions have significantly reduced cooperation and created new barriers of entry for foreign investors. As a result, companies from the US and the EU as well as Russia and Iran are looking for ways to circumvent these restrictions and barriers of entry. One of the most optimal solutions can be the use of Armenia and its potential. Being a member of the Eurasian Economic Union and one of good neighbors of Iran, Armenia continues to build strong relations with the USA and the EU countries. Therefore, Armenia can become a platform for dialogue between businesses from these countries. It can help them to build new business relationships and avoid restrictions imposed by mutual sanctions. Due 
to the mentioned geopolitical and economic situation, the Armenian market was selected for the analysis of attractiveness to investors.

To conclude, this article will result in determining indicators that will help investors evaluate the attractiveness of foreign markets. By comparing Armenian market with another market (in this article, with Poland), it will become more obvious where the county's government should make noticeable changes. Taking into account Poland's case can be very helpful, as Poland is a good example of a county which has developed in a short period of time.

\section{CRITERIA FOR ASSESSING THE ATTRACTIVENESS OF FOREIGN MARKETS}

Several market selection models appear in the literature and their aim is to try to formalize the decision-making process by the investor. The choice of a foreign market is a sequence of activities that gradually eliminate less attractive countries from the point of view of a particular investor (Koch, 2001). The assessment of attractiveness and the process of selecting the target country can be divided into three stages: preliminary research, identification and selection (Górecka \& Szałucka, 2013). At the first stage, investors use indicators to assess the macro environment in order to eliminate countries that do not meet the necessary requirements. At the identification stage, the attractiveness of the sector of economy which the investor intends to enter is assessed. He collects information specific to that industry in order to select countries with high market potential. During the selection phase, the investor focuses on enterprise-specific information, trying to answer the question of whether the factors which are specific to his investment idea can guarantee the achievement of a competitive advantage in a particular country. The final selection should clarify whether the domestic market meets the investor's goals.

The initial country selection process (Górecka \& Szałucka, 2013) can only be effective if it allows the identification of markets with great potential from the investor's point of view by comparing and assessing the country's characteristics. The comparison criteria must be selected in advance and should maximally reflect the market situation of the country that they concern. Unfortunately, there is not one common approach as regards which criteria should be used and how to measure them. Various authors propose their ways of measuring the attractiveness of countries that are based on different criteria. These criteria vary depending on what goals a given entity or investor has, what industry it plans to enter, what products it wants to produce and what entry strategy it wants to use. Criteria most commonly used by different authors are the size of markets and the level of economic development of target countries. In practice, more detailed criteria for assessing the attractiveness of a country are applied and the number of these criteria is much broader. In order to guarantee low costs, flexibility and simplicity of the country preselection, most models focus on analyzing the macro factors of target countries. The next step is the selection of indicators for measuring selected criteria. These indicators should explain the specifics of the chosen criteria as much as possible and must be considered as reliable. This choice helps to avoid subjectivism in the process of evaluating markets. Another problem that arises during the process of choosing a foreign market is the issue of assigning weights to the criteria for assessment. There is no unanimity in assigning weights to criteria, reflecting the relative importance of each of them. Some approaches argue that all weights used for the selected criteria should be equal, while others argue inversely that some criteria are more important than others (Russow \& Okoroafo, 1996).

In this paper, several criteria were selected based on the recommendations of well-known authors and on the basis of PESTEL and SWOT analyses. These criteria are the most appropriate in a given situation and can best explain the specificity of each country. The indicators assessing each of the selected criteria are selected for their reliability and acceptability by various global institutions. The method assigning different weights to each of the criteria has been used. This 
results from the fact that this work is aimed at examining the attractiveness of countries by showing the different importance of selected assessment criteria to the investor. For example, the ability of the public to use foreign languages influences investment decisions of a foreign entity, but its validity is much smaller than the importance of economic growth or political stability in a given target country. This results from the fact that some of the criteria have a direct impact on the organization's success when other criteria are supportive. The assessment is to explain the sensibility of entering a specific domestic market for both direct and indirect investors (Investopedia, n.d.). If, in the case of direct investors, the situation in the target industry is very important, in the case of indirect investors, the general economic situation of a given country is more important, and the industry situation has a secondary role. Then, after presenting all the criteria for the assessment of foreign markets, the indicators serving this analysis and the weights that show the relative importance of each of these criteria to a foreign investor, the reasons for choosing each criterion, indicator and weight will be explained one after another.

The next stage of the analysis is the identification process. After explaining the attractiveness of the country, the investor should focus on specific industries of the country that interest him. During the identifying phase, the investor should evaluate the attractiveness of the target industry. You can construct a table similar to Table 1. In this new table, depending on the specificity of the industry, you can delete or add new assessment criteria and you have to assign a different weight to each criterion because each criterion, depending on the industry, will have different impact on the investor's success - sometimes larger, sometimes smaller.

If the investor positively assesses the attractiveness of the industry, then at the end he should focus on marketing and production tools that are worth applying in order to achieve the planned market position.

In this part, it is also worth paying attention to the fact that geographic proximity, cultural closeness and mental closeness play an important role for the investor (Karasiewicz \& Lemanowicz, n.d.). These factors can significantly reduce the costs and barriers to entering a new market. As a result, the risk of failure will be much smaller than in the case of investing in a country with specific features which are unknown to the investor.

From the point of view of the country, improvement and reform of each of the criteria which were marked in Table 1 may increase the chances of obtaining additional funds from abroad. This action will probably increase the competitiveness of a given country and multiply attractiveness to investors. The policy of sustainable development of each of the assessment criteria will probably become the foundation for building a strong country that can become a powerful global force in the future. That is why government representatives should carefully analyze these criteria and develop a strategic plan to improve the factors that negatively affect the attractiveness of the entire country.

\section{SELECTION OF CRITERIA, INDICATORS AND WEIGHTS TO ASSESS THE ATTRACTIVENESS OF FOREIGN MARKETS}

The factors selected to assess the attractiveness of a country can be divided into 5 groups: political and legal, economic, socio-cultural, technological and environmental factors, and others. These are the most important areas of the enterprise macro environment. By examining these factors, a foreign investor will be able to assess all the opportunities or threats that may arise in his macro environment when entering a new geographic market. For each of these factors, several criteria have been selected that can describe their specificity to the maximum. The evaluation of individual criteria will be carried out with the help of reliable and universally accepted indicators which were formulated on the basis of statistical data analysis, reports from previous research and 
studies carried out by various world institutions. All of these indicators are in open public access, so any entrepreneur can use them to conduct their own market research.

The following criteria describe political and legal factors: political stability, the level of corruption and business friendly regulations. Political stability in the target country is measured by using the index of political stability (The Global Economy, 2017), which assesses the effectiveness of governments, the level of violence and overall stability in the country. Corruption level is measured by the corruption perceptions index (Transparency International, 2017). This indicator shows the possibility of fair competition in the market. Business friendly regulations (The World Bank, Ease of doing business index, 2018) are described by the index of ease of establishing a business. This index describes the regulations for business and the level of protection of property rights.

Economic factors are illustrated with the help of five criteria: unemployment rate, economic growth, inflation level, the level of citizens' well-being, tax rate. These criteria can be easily presented using common economic indicators that give basic information about the economic situation in the analyzed country. These indicators are: the unemployment rate in a given country (percentage share of people who do not work in society) (Trading Economics, Unemployment rate, 2018), GDP growth (the rate of growth of the country's economy) (The World Bank, GDP growth (annual \%), 2018), inflation rate (change in the value of money over time) (Trading Economics, Inflation rate, 2018), GDP per capita (the level of the citizens' well-being) (The World Bank, GDP per capita (current US\$), 2018) and income tax (CIT amount) (KPMG, 2018). Using the data obtained from these measures, one can easily describe the economic situation in the target country and assess the attractiveness of the economy of a given country.

Socio-cultural factors are also presented using five criteria and five indicators that describe these criteria. Social inequality in the target country is presented using the GINI index (The World Bank, GINI index, 2018). This ratio shows the differences in income of the citizens of the analyzed country. Demographic changes are shown using the percentage of population growth rate (The World Bank, Population growth (annual \%), 2018). Therefore, with the help of this data, one can easily say how much the country's population has changed in the analyzed period. The level of social development is described by Human Development Index (HDI) (United Nations Development Programme, 2018). The Human Development Index (HDI) was created by the United Nations as an indicator assessing the level of social and economic aspiration in various countries. This index makes it possible to follow changes in levels of development over time and compare development levels of different countries and nations. Masculinity/femininity is best described by the Gender Inequality Index (GII) (United Nations Development Programme, 2018), which shows the level of women's involvement in social, political and economic life. The level of religiosity of the country is shown by the indicator of the importance of religion (Gallup, 2009). This index tells us what percentage of a country's society treats religions as a very important part of their lives.

The following criteria for assessing the attractiveness of a country to foreign investors are presented for the technological and environmental factors: technologies, infrastructure, war/peace. Internet access is used to measure the level of technological advancement (Internet live stats, 2016). This indicator tells you which part of the country's population is connected to the global network. The infrastructure is explained using the Logistics Performance Index (LPI) (The World Bank, Logistics performance index, 2018). LPI shows the ease of transferring goods and services to the buyer. The war has a big impact on almost every aspect of the country's functioning. The war/peace criterion could really be placed under each of the five proposed factors, but it is considered as one of technological and environmental factors due to the fact that technological advancement is a decisive factor as regards armed conflicts and war has a huge impact on the natural environment of the country. Global Peace Indicator (GPI) shows the probability of war in almost every country in the world (Country Economy, 2018). 
Other factors that may have an impact on the attractiveness of a foreign market include the following criteria: language barriers, size of the potential market, foreign direct investment. The English proficiency indicator can be used to assess language barriers (EF, 2018). The size of the potential market can be represented by the population of countries with which an entity operating in a given area can act without restrictions and barriers (Worldometers, 2018). The criterion of foreign direct investment may be assessed using the percentage share of FDI in the GDP of the target country (The Global Economy, 2017). This indicator contains information on the dependence of the state economy on foreign capital.

The next stage in the construction of the table assessing the country's attractiveness for foreign investment should be the introduction of a uniform scale for all criteria. This will facilitate the process of assessing and comparing countries. In this work, all indicators will be recalculated to a scale from 0 to 10 . Considering that the indicators are presented in different units of measure, the process and techniques for converting them to a ten-point range will be shown during a practical comparative analysis of the two countries.

The last step in constructing the table is the process of using the scales for each of the criteria that will maximally explain their significance from the point of view of the foreign investor. Conditionally, these criteria for the assessment of foreign markets can be divided into two groups. The first group are the criteria that have great importance for the investor. Therefore, the lack of a satisfactory level of even one of these criteria may stop the entrepreneur from investing. That is why the weight of these indicators will be greater. But it is also worth noting that the weightings of the criteria of this first group are not very different. These weights were designed after analyzing various techniques that can be found in the literature on the subject (Birnleitner, 2014). This group includes: business-friendly regulations, tax amount, economic growth, corruption level, infrastructure, political stability, potential market size, war/peace, technologies, inflation, level of social development, social inequality, citizens' well-being. The second group includes the criteria that obviously have an impact on the investment decisions of the economic entity, but their strength is lesser compared to the first group. A satisfactory level of these indicators can be an additional advantage for the investor. The second group includes the following criteria: unemployment rate, demographics, foreign direct investment, language barriers, religion, masculinity/femininity.

Table 1

A list of criteria, indicators and weights for assessing the attractiveness of foreign markets

\begin{tabular}{|c|c|c|c|c|}
\hline Factors & № & Criteria & Indicators & Weight \\
\hline \multirow{3}{*}{$\begin{array}{l}\text { Political and legal } \\
\text { factors }\end{array}$} & 1.1 & Political stability & Index of political stability & 0.059 \\
\hline & 1.2 & The level of corruption & Corruption perceptions index & 0.06 \\
\hline & 1.3 & Business friendly regulations & Ease of doing business index & 0.063 \\
\hline \multirow{5}{*}{ Economic factors } & 2.1 & The level of unemployment & Unemployment rate & 0.049 \\
\hline & 2.2 & Economic growth & GDP growth rate & 0.061 \\
\hline & 2.3 & Inflation & Inflation rate & 0.055 \\
\hline & 2.4 & $\begin{array}{l}\text { The level of citizens' } \\
\text { well-being }\end{array}$ & GDP per capita & 0.052 \\
\hline & 2.5 & Tax rate & Corporate tax rate & 0.062 \\
\hline
\end{tabular}




\begin{tabular}{|c|c|c|c|c|}
\hline Factors & № & Criteria & Indicators & Weight \\
\hline \multirow{5}{*}{ Socio-cultural factors } & 3.1 & Social inequality & GINI index & 0.052 \\
\hline & 3.2 & Demographics & Population growth index & 0.047 \\
\hline & 3.3 & $\begin{array}{l}\text { The level of social } \\
\text { development }\end{array}$ & Human Development Index (HDI) & 0.052 \\
\hline & 3.4 & Masculinity/femininity & Gender Inequality Index (GII) & 0.035 \\
\hline & 3.5 & Religion & Indicator of the importance of religion & 0.039 \\
\hline \multirow{3}{*}{$\begin{array}{l}\text { Technological and } \\
\text { environmental factors }\end{array}$} & 4.1 & Technologies & Internet access & 0.055 \\
\hline & 4.2 & Infrastructure & Logistics Performance Indicator (LPI) & 0.059 \\
\hline & 4.3 & War/peace & Global Peace Index (GPI) & 0.055 \\
\hline \multirow{3}{*}{ Other factors } & 5.1 & Language barriers & $\begin{array}{l}\text { Knowledge of English language } \\
\text { by country }\end{array}$ & 0.044 \\
\hline & 5.2 & $\begin{array}{l}\text { The size of the potential } \\
\text { market }\end{array}$ & Population & 0.056 \\
\hline & 5.3 & Foreign Direct Investment & Percentage of FDI in GDP & 0.045 \\
\hline
\end{tabular}

Source: own study.

Table No. 1 presents selected criteria that, after having been assessed by the investor, will make it possible for the investor to answer the question whether the analyzed country meets all his basic requirements and whether it is still attractive for him. In this subsection, the concept of assessing the attractiveness of foreign markets is proposed. In the following chapter, an example of two countries will be shown.

\section{COMPARING THE ATTRACTIVENESS OF ARMENIA AND POLAND}

At first glance, one can say that comparing Armenia with Poland will lead to unequivocal conclusions that Poland is more attractive to foreign investors in terms of almost all evaluation criteria. It may seem that it will be difficult to make any comparison of these two countries because they exist in different economic, geopolitical and social realities. But this work, by assessing the attractiveness of Armenia and Poland, aims to explain what factors are of key importance to the attractiveness of Poland and what reforms may be beneficial and useful for Armenia.

\subsection{Comparing the Geopolitical Situation of Armenia and Poland}

Clearly, the geopolitical situation and the position of the state in the international arena have a direct impact on the attractiveness of the country to investors from different parts of the world. So, it is worth trying to look at the position of Armenia and Poland in international relations. You also need to compare which world centers of power have the greatest influence on these two countries.

Poland in the early nineties came out of Russia's interest zone because the USSR collapsed. The lack of Russian influence allowed the United States and the European Union to intensify contacts with Poland in various economic, social and political areas. This positively affected Poland due to the fact that the US and the EU invested in the country through various funds, grants and programs. These measures were intended to help the country rebuild the economy, normalize social life, and gradually increase the dependence of political decisions on the position of the US and the EU. This fact should not be treated as a negative or positive phenomenon. This is 
a situation characteristic of every episode of human history - strong economic and social ties will lead to the strengthening of political relations. In the next stage, when Poland joined the European Union, these relations became even deeper. Poland has become one of the largest beneficiaries of EU funds, the abolition of customs barriers has allowed Polish entrepreneurs unlimited access to the EU market. As a result, Poland and the EU have unified approaches concerning most global problems. The accession of Poland to NATO is also very important because most of the members of this organization are in the EU, and the USA is the most powerful force of this treaty. In this way, Poles associate the defense issues of their country with the same countries with which they develop the economy together. This can be treated as a partial loss of sovereignty, but it is worth taking into account that the other EU and NATO countries have a similar situation and in fact Poland is gaining from this type of cooperation.

Common approaches of Poland and the above-mentioned countries to economic, social and defense policy issues are a strong impulse for investors from these countries saying that Poland has a similar vision of development to that of their countries. On the other hand, numerous international agreements will provide a similar level of security for the funds invested.

All this led to an increase in investments from both EU countries and some key NATO countries. The investment possibilities of these countries are enormous because the majority of them are developed countries. The decisions taken concerning the choice of strategic partners of Poland and the reforms and changes related to the requirements of these alliances have increased the country's attractiveness in the eyes of foreign investors and led to economic growth.

Armenia is heavily influenced by Russian politics. Russia has its strategic goals in this region, so letting go of Armenia from its sphere of influence can have tragic consequences for the Federation. And this is the most important reason why Russia is taking all steps to make Armenia participate in all integration processes with Russia. Armenia became a member of EAEU (Eurasian Economic Union) and CSTO (Collective Security Treaty Organization). It is very important that the EAEU and CSTO countries are developing countries. This means that the investment possibilities of entrepreneurs from these countries, funds allocated for the development of the member states of the union and the purchasing power of the societies of these countries are very limited. In addition, the common EAUG market is almost 2 times smaller than in the EU. At first sight, this choice of Armenians may not seem optimal. But such a decision resulted from a specific geographical and political situation in the region (tense relations with Turkey, the war with Azerbaijan, sanctions against Iran). Taking into account the aforementioned situation, economic difficulties, large expenditures on armaments and general tenseness in this region and in the Middle East, it can certainly be said that Armenia is currently in worse starting conditions than Poland in the nineties.

The most important problem of Armenia is how to make the most of the current geopolitical situation while remaining a member of the EAEU and CSTO. The example of Poland may be very interesting to draw good conclusions that may have a key role in the process of making Armenia more attractive to foreign investors. After comparing the attractiveness of Armenia and Poland, proposals will be presented, with Poland as the example, that can guarantee stable economic growth of the country.

\subsection{Comparing the Attractiveness of Poland and Armenia}

In this sub-section, the values of previously selected indicators for each chosen country will be presented. Some of these indicators will have a negative impact and some will have a positive impact on the final assessment of the country's attractiveness. Then, these indicators will be converted to a range from one to ten in order to easily compare the two countries. 
Table 2

Indicators characterizing Armenia and Poland

\begin{tabular}{|c|c|c|c|c|c|c|}
\hline Factors & № & Criteria & Indicators & Armenia & Poland & Weight \\
\hline \multirow{3}{*}{$\begin{array}{l}\text { Political } \\
\text { and legal } \\
\text { factors }\end{array}$} & 1.1 & Political stability & Index of political stability & -0.6 & 0.51 & 0.059 \\
\hline & 1.2 & The level of corruption & Corruption perceptions index & 35 & 60 & 0.06 \\
\hline & 1.3 & $\begin{array}{l}\text { Business friendly } \\
\text { regulations }\end{array}$ & Ease of doing business index & 72.51 & 77.3 & 0.063 \\
\hline \multirow{5}{*}{$\begin{array}{l}\text { Economic } \\
\text { factors }\end{array}$} & 2.1 & $\begin{array}{l}\text { The level of } \\
\text { unemployment }\end{array}$ & Unemployment rate & $18 \%$ & $6.60 \%$ & $5 \%$ \\
\hline & 2.2 & Economic growth & GDP growth rate & $0.60 \%$ & $2.90 \%$ & $6.10 \%$ \\
\hline & 2.3 & Inflation & Inflation rate & $-1.30 \%$ & $0.90 \%$ & $5.50 \%$ \\
\hline & 2.4 & $\begin{array}{l}\text { The level of citizens' } \\
\text { well-being }\end{array}$ & GDP per capita & 3.92 & 15.04 & 0.052 \\
\hline & 2.5 & Tax rate & Corporate tax rate & $19 \%$ & $20 \%$ & $6 \%$ \\
\hline \multirow{5}{*}{$\begin{array}{l}\text { Socio-cultural } \\
\text { factors }\end{array}$} & 3.1 & Social inequality & GINI index & 32.5 & 31.8 & 0.052 \\
\hline & 3.2 & Demographics & Population growth index & $0.30 \%$ & $-0.01 \%$ & $4.70 \%$ \\
\hline & 3.3 & $\begin{array}{l}\text { The level of social } \\
\text { development }\end{array}$ & Human Development Index (HDI) & 0.743 & 0.855 & 0.052 \\
\hline & 3.4 & Masculinity/femininity & Gender Inequality Index (GII) & 0.293 & 0.137 & 0.035 \\
\hline & 3.5 & Religion & $\begin{array}{l}\text { Indicator of the importance } \\
\text { of religion }\end{array}$ & $73 \%$ & $75 \%$ & $4 \%$ \\
\hline \multirow{3}{*}{$\begin{array}{l}\text { Technological } \\
\text { and } \\
\text { environmental } \\
\text { factors }\end{array}$} & 4.1 & Technologies & Internet access & $49.90 \%$ & $72.40 \%$ & $5.50 \%$ \\
\hline & 4.2 & Infrastructure & $\begin{array}{l}\text { Logistics Performance Indicator } \\
\text { (LPI) }\end{array}$ & 2.21 & 3.43 & 0.059 \\
\hline & 4.3 & War/peace & Global Peace Index (GPI) & 2.22 & 1.676 & 0.055 \\
\hline \multirow{3}{*}{ Other factors } & 5.1 & Language barriers & $\begin{array}{l}\text { Knowledge of English language by } \\
\text { country }\end{array}$ & $40 \%$ & $62 \%$ & $4 \%$ \\
\hline & 5.2 & $\begin{array}{l}\text { The size of the potential } \\
\text { market }\end{array}$ & Population & 262 & 512 & 0.056 \\
\hline & 5.3 & $\begin{array}{l}\text { Foreign Direct } \\
\text { Investment }\end{array}$ & Percentage of FDI in GDP & $3.20 \%$ & $3.56 \%$ & $4.50 \%$ \\
\hline
\end{tabular}

Source: own study.

In terms of a ten-point system, the indicators which are presented in percentages will be divided by 10 . The indicators which are measured in the range from 0 to 100 will also be divided by 10 . Indicators that are measured in other ranges will be proportionally converted into a tenpoint system; in the case of GDP per capita, the maximum value of 10 was allocated to the country with the highest GDP per capita (Luxembourg - USD 100,738) and the compared countries got points proportional to Luxembourg. In the case of potential market size, 10 points were given to a theoretical country that could have unlimited access to the entire population of the world. Negative indicators will appear when the indicator has a negative impact on the country's attractiveness. 
Table 3

Comparing Armenia with Poland

\begin{tabular}{|c|c|c|c|c|c|}
\hline \multirow{2}{*}{ Indicators } & \multicolumn{2}{|c|}{ Points } & \multirow{2}{*}{ Weight } & \multicolumn{2}{|c|}{ Points X Weight } \\
\hline & Armenia & Poland & & Armenia & Poland \\
\hline Index of political stability & 3.8 & 6.02 & 0.059 & 0.2242 & 0.35518 \\
\hline Corruption perceptions index & 3.5 & 6 & 0.06 & 0.21 & 0.36 \\
\hline Ease of doing business index & 7.251 & 7.73 & 0.063 & 0.456813 & 0.48699 \\
\hline Unemployment rate & -1.8 & -0.66 & 0.049 & -0.0882 & -0.03234 \\
\hline GDP growth rate & 0.06 & 0.29 & 0.061 & 0.00366 & 0.01769 \\
\hline Inflation rate & -0.19 & -0.09 & 0.055 & -0.01045 & -0.00495 \\
\hline GDP per capita & 0.39 & 1.49 & 0.052 & 0.02028 & 0.07748 \\
\hline Corporate tax rate & -1.9 & -2 & 0.062 & -0.1178 & -0.124 \\
\hline GINI index & -3.25 & -3.18 & 0.052 & -0.169 & -0.16536 \\
\hline Population growth index & 0.03 & -0.001 & 0.047 & 0.00141 & $-4.7 \mathrm{E}-05$ \\
\hline Human Development Index (HDI) & 7.43 & 8.55 & 0.052 & 0.38636 & 0.4446 \\
\hline Gender Inequality Index (GII) & -2.93 & -1.37 & 0.035 & -0.10255 & -0.04795 \\
\hline Indicator of the importance of religion & 7.3 & 7.5 & 0.039 & 0.2847 & 0.2925 \\
\hline Internet access & 4.99 & 7.24 & 0.055 & 0.27445 & 0.3982 \\
\hline Logistics Performance Indicator (LPI) & 4.42 & 6.86 & 0.059 & 0.26078 & 0.40474 \\
\hline Global Peace Index (GPI) & -5.55 & -4.19 & 0.055 & -0.30525 & -0.23045 \\
\hline Knowledge of English language by country & 4 & 6.2 & 0.044 & 0.176 & 0.2728 \\
\hline Population & 0.345 & 0.674 & 0.056 & 0.01932 & 0.037744 \\
\hline Percentage of FDI in GDP & 0.32 & 0.356 & 0.045 & 0.0144 & 0.01602 \\
\hline SUM & & & & 1.54 & 2.56 \\
\hline
\end{tabular}

Source: own study.

Table No 3 presents the sum of all indicators taking into account the weight of each criterion. The final rating of Armenia equals 1.54 points multiplied by weight and Poland's stands at 2.56. Consequently, if countries are assessed with the above-mentioned criteria, Poland is more attractive to foreign investors than Armenia. So, if an investor has to choose where his investments are more likely to succeed, in Armenia or Poland, he has to choose Poland without hesitation. As already emphasized, this conclusion was obvious because Poland can be included among developed countries and Armenia is a developing country. But this work aims not only to compare these two countries but also, taking into account the geopolitical, cultural and national specificity of each of these countries, to show what actions may allow Armenia to achieve similar success to Poland.

\section{POSSIBILITIES TO APPLY POLISH EXPERIENCE IN ARMENIA}

Poland's accession to the European Union had not only economic but also political reasons. The EU countries wanted to have access to Poland's strengths such as cheap and qualified workforce, natural resources, a large internal market, good strategic geographical location and enormous economic potential. From the point of view of Poland, by adopting the decision to 
join the EU, the country tried to use the opportunities that could arise, use its unique strengths to achieve a competitive advantage, reduce the negative impact of threats and mitigate its weaknesses. Summing up, it is a mutually beneficial decision for both EU countries and Poland. The difference between Armenia and Poland is the choice of strategic partners and the use of their investment potential. The economic union to which Armenia belongs is now definitely weaker and poorer than the EU, but as already underlined, accession to EAUG resulted from a specific regional situation. This, of course, partially limits the country's development opportunities, but Armenia can succeed if it makes the right decisions and pursue diversified policy.

But Poland can be a good example for Armenia because the country is open and ready for dialogue not only with EU countries but also, for example, with the US, which is not a member of this Union but wants to have maximum and unlimited access to this huge market. The proof of this is that in 2016 the largest direct foreign investor in Poland was the United States (EY, 2017). Poland is also developing good mutually beneficial relations with China. This is evidenced by the trade turnover between the two countries. China is currently Poland's second largest trading partner after Germany (Central Statistical Office (Poland), 2017). This shows that, despite belonging to a specific economic union, the country continues to develop relations with other centers of power in the world. So, the most important task of the Armenian government should be to increase the country's attractiveness to investors outside the Eurasian Economic Union. This will help to make investments necessary for the economic development of the country, which investors from the EAEU countries are unable to offer due to economic problems and sanctions. The most difficult question appears: how can this be done?

For Armenia, political and legal factors - political stability and the level of corruption - will be relatively easy to improve. One of the basic reasons for Poland's success and attractiveness to foreign investors is the rapid stabilization of the political situation in the country and the overcoming of corruption immediately after the collapse of the communist system. This is evidenced by the fact that already in 1998 Poland was in quite high positions in two rankings (The Global Economy, 2017; Transparency International, 2017). Therefore, Armenia should solve these problems as quickly as possible. This can be accomplished by, for example, curbing crime and legitimizing the state, improving the quality of public services, guaranteeing equal legal treatment for all, better protection of human rights, preventing the irremovability of ruling elites and fighting monopolies. In terms of the index of ease of doing business, both countries have quite good positions, but of course they should systematically examine this area and, if necessary, apply necessary solutions.

The theory of the Phillips curve (McConnell, Brue, \& Flynn, 2011) states that along with economic growth, inflation is growing, which in turn should lead to an increase in the number of jobs and a reduction in unemployment. It follows that the economic factors presented in Table 3 (unemployment rate, economic growth, inflation, the level of citizens' well-being) are directly related to each other. The example of Poland shows that since the beginning of decommunization, the country's GDP has grown (Trading Economics, 2018) and the unemployment rate in the country was not high (Central Statistical Office (Poland), 2017), but at the same time inflation in Poland was low, in particular in 1998-2017 (Inflation.eu, 2018). The Balcerowicz Plan (Czarny, 2005), subsequent economic decisions and finally the entry to the European Union had a clear impact on the direction and pace of growth of the country's economy. Economic growth, low unemployment and inflation in Poland have key importance for investors and that is why the country is becoming more and more attractive to them. On the other hand, Poland has tried to maximize the strengths of its economy (skills of local employees, the potential for productivity growth and low employment costs) and develop certain sectors of its own economy (production, finance and business services, transport and communication). That is why these sectors are still attractive to foreign investments. Currently, taking into account the above-mentioned strong 
sides of the state, the vast majority of foreign entities enter these three sectors because they are sure that this will provide them with profits not only in the short term but also in the long term.

Armenia should strive to record rapid economic growth as soon as possible. This will lead to a reduction in unemployment, which is currently a very serious problem for the country. But at the same time, the country needs to control the level of inflation. Growing consumer spending, investment levels, government spending and exports will lead to an increase in total demand and GDP of the country. In this case, there is the problem of inflation increase, so the Armenian government also has to try to increase the total supply to limit the price growth. The total supply may increase, for example, due to the development of new technologies, introduction of new management techniques, improvement of workers' skills and qualifications, more flexible job opportunities, public sector investment - for example by improving infrastructure, increasing education spending, etc. With an appropriate fiscal and monetary policy, Armenia will be able to compete for foreign investors' money with the leaders of this market. Of course, not all solutions used in Poland to develop the economy will be useful for Armenia because countries exist in different realities, but the example of Poland shows that a smart macro- and microeconomic policy is directly related to the process of making the country more attractive to foreign investors. But unambiguously Armenia, like Poland once, should clearly inform the world about its strengths and then show those industries where these strengths can be as useful as possible.

The level of taxes in two countries is not very different. The taxation method, government subsidies for priority sectors, tax incentives for some entities and industries and the amount of taxes play a very important role in the process of country selection by foreign investors. The government tax and subsidy strategy may have both a positive and a negative impact on attractiveness. So, the country should constantly monitor the expectations of investors who may be interested in the country in the future and, on the basis of these data, develop a taxation strategy that takes into account the expectations of these investors. In this case, the chances are higher that, thanks to such incentives, the investor will be convinced and eventually enter the market. In Poland, even at the level of regions, incentives for investors are available, such as the exemption from CIT in so-called Special Economic Zones (SEZ), government subsidies (support from the national budget), cash subsidies or loans from EU funds, etc (Moore Stephens Europe, 2017). These and other tax incentives applied by Poland should be analyzed by Armenia and adapted to the realities of the Armenian economy.

In the case of socio-cultural factors, the indicators which describe social inequality, the level of social development and gender inequality may also be improved in the short term. The GINI index in both countries is not high. This means that there is an equal distribution of income in society in both Armenia and Poland. According to the Human Development Index (HDI), the level of socio-economic development of Armenia is lower than that of Poland. HDI is a summary measure of progress in three basic dimensions of human development - long and healthy life, access to knowledge and standards of living. In the years 1990-2015, the value of HDI in Poland increased from 0.712 to 0.855 , by $20.1 \%$. In the years 1990-2015, the average life expectancy in Poland increased by 6.7 years, the average number of years of education increased by 2.2 years, and the expected years of education increased by 4.1 years. The Polish GNI per capita increased by approximately $150.9 \%$ (United Nations Development Program, 2016). It follows that state investments in the sphere of education, positive health reforms and solutions to problems that concern a greater part of society will lead to a greater level of satisfaction of the citizens of Armenia. So, Armenia should take all actions to increase this index because a well-educated, happy and healthy society is better focused on work and has fewer troubles characteristic of poor people. On the other hand, there appears the opportunity to introduce the concept of common good of the nation and the country can increase its chances of building a strong economy and attract more foreign investment. 
The involvement of women in Armenia's economic life is also at a lower level than in Poland. A good proof of the fact that Poland is in the forefront of the world is that $40 \%$ of managerial positions in Poland are occupied by women (Grant Thornton, 2017). If Armenia carries out appropriate actions to increase the level of education, skills and involvement of women in the economy, the number of qualified workers can significantly increase. An increase in the number of trained specialists will be unequivocally noticed by foreign investors. This will be an additional advantage of Armenia as a prospective target country for investors. On the other hand, the feminist trend shows that similar actions can have a positive impact on the image of the country.

Currently, both Armenia and Poland have a problem related to demographics. An aging population can lead to the redistribution of income. Demographic problems can change the structure of consumption and pension systems (Raczaszek, 2012). And this in turn may have an impact on the decisions of foreign investors. So, both countries face the need to find good solutions. Since 2016, the 500+ (Government of Poland, n.d.) program has been implemented in Poland, but it is still difficult to assess the results. In Armenia, similar programs also exist, but they are not very successful.

In both analyzed countries, religion has a very important role. Christianity is very deeply rooted in both Armenia and Poland. Religion can play an important role in the development and maintenance of a fair economy because a healthy economy requires that people look at others with esteem and do not treat them as objects of exploitation. Religion calls on people to respect everyone, regardless of their class and cultural background. This in turn means respect for work and property. Competition ensures that wages and prices reflect the fair representation of the work contained in the product (Davies, 2004). At the same time, a large percentage of those who claim that religion has a huge role in their lives testify to a common system of values and similar worldviews. These views may be shared by other nations that have the same faith. For foreign investors, religiosity of the country testifies to the possibility of fair competition and clear rules of communication with the target group (what is allowed and what is not allowed in this country).

The country's economic growth has a significant impact on these socio-economic indicators. On the other hand, improving these indicators may have a positive impact on the economy and on the process of making the country more attractive to foreign investors.

Technology has a profound impact on the global economy. This led to the transformation of the market, improvement of living standards and facilitation of international trade processes. Technological progress significantly improved the business process and lowered its costs. Advances in the computer industry, along with advances in telecommunications, increased employment opportunities and strengthened economic growth. All physical barriers to distance communication have been effectively minimized with the help of the Internet. It is worth noting that technological development also positively influences the innovation of countries and entities operating in them. Therefore, the level of technology development in the target country is of key importance to investors. In Poland, the IT industry is one of the most important sectors of the national economy, with huge prospects for future development. Some aspects, such as state budget compensation, available qualified specialists or rapid market development, affect the industry. On the other hand, the presence of international giants on the Polish market is also beneficial for the state. Generally, in developed countries such as Poland, technological advancement is at a higher level than in developing countries (ITSG Global, 2017). Given the high importance of technological progress for the economy and social life of countries, Armenia should try to further develop technology in order to make its market more attractive to investors from around the world.

Infrastructure is a basic condition for economic development. It does not directly produce goods and services but facilitates delivery to the buyer. The level of economic development in each country depends on the development of infrastructure. Infrastructure can be defined as those basic devices and services that facilitate various types of economic activity and thus can help the 
economic development of the country. Education, health, transport and communication, banking and insurance, energy, science and technology, etc., are examples of infrastructure. EU funds, government investments and a favorable geographical location of Poland allowed Poland to develop the infrastructure in the country, which led to economic growth. The EU membership has increased the importance of infrastructure because after the production of goods and services it is necessary to deliver them safely and quickly to the buyer. In Armenia, the infrastructure problem is very serious. Due to the closed borders with Azerbaijan and Turkey, the mountainous landscape of the country makes it difficult to physically transport products from the country. Of course, activities are carried out to maximize the use of all existing opportunities and attempts have been made to focus on a more technologically advanced infrastructural solution. Due to the complicated geopolitical situation of this region, Armenia's importance as a transit country is growing, so the rapid development of the country's infrastructure is important not only for Armenia but also for Iran and Russia, for example. As in the case of Poland, Armenia may also take advantage of its geographical location to engage Russian and Iranian investors in infrastructure projects or to require money from the EAEU common budget for these purposes.

The war has a negative impact on the economies of countries and their attractiveness to foreign investors because it becomes difficult to guarantee security or return on the funds invested. On the other hand, war is an additional cost for the state budget and results in the loss of qualified employees. Under this criterion, it is difficult to compare Armenia with Poland because one of these countries is even now at war, which is in a cold phase but can start with a new force at any moment. What may be beneficial for Armenia is the analysis of Polish-German relations. Germany's involvement in the Polish economy, building new jobs for Poles and investments in various programs have reduced the negative attitude of Poles to Germany, which was present after the Second World War. But such a solution is very unlikely at the present moment because there are no real contacts between businessmen from Armenia and Azerbaijan. Currently, the Armenian government is conducting all necessary activities that can show foreign investors that this war does not affect the business environment, the government controls the situation and there are no threats to their capital.

Knowledge of foreign languages and the ability to communicate is very important for investors. Foreign investors should be able to build their business without encountering language barriers. This problem can be solved with the help of educational or training programs. Both in Armenia and in Poland, the youth are able to speak at least two languages. Problems arise with older generations. In terms of knowledge of English, which is now widely used for business, a larger percentage of Poles are able to communicate with investors. In Armenia, this percentage is smaller, but this situation is changing, thanks to reforms in the sphere of education. This is an important phenomenon that may persuade investors from all over the world to enter the Armenian market.

The size of the potential market is crucial for foreign investors when making decisions on entering a new country. Therefore, the investor should offer his products and services in a way that satisfies not only the internal needs of the target country but also the entire potential market. The whole market of the European Union is a potential market for Poland because a product or service created in Poland can be sent to the countries of this union without encountering trade barriers. The EU market not only is large in terms of population but also has huge purchasing possibilities, which is very good information for entities planning to start operations in Poland. The potential market of Armenia includes the market of the Eurasian Economic Union. This market is more than 2 times smaller than the EU market and the purchasing power of society is significantly reduced. In any case, Armenia's unrestricted access to the EAEU market in combination with the strengths of the country may be attractive to foreign investors, in particular those who, due to sanctions, cannot trade with Russia directly. So, the development of this union and the harmonization of existing regulations will positively affect the attractiveness of Armenia. 
Foreign direct investment is one of the forms of entry into foreign markets. Poland's membership of the EU had a positive impact on the inflow of foreign investment. Enterprises from around the world, in particular from EU countries, started to invest in Poland. New jobs, know-how and greater experience of employees are only a small part of the profits made by Poland. At present, Armenia is in the situation in which Poland was in 2004 after accession to the EU. Armenia should show, both to entities from EAUG countries and the rest of the world, that all the country's strengths and opportunities that may arise will have a positive impact on the investor, and the weaknesses and threats are controlled as much as possible. In this case, the attractiveness of the country and the inflow of investments will increase.

\section{CONCLUSION}

On the basis of the previous comparative analysis of Armenia and Poland, taking into account the reasons for rapid economic development of Poland, several conclusions can be drawn that will have strategic importance for the intensification of Armenia's development, which will lead to increased interest of foreign investors in this country. So, Armenia should remain a member of the EAEU and CSTO to gain the maximum from the opportunities that appear on the international scene. In this way, the country will be able to diversify its partners and reduce its economic and political dependence on one country or organization. For this purpose, Armenia may try, for example, to maximize duty-free access to the CIS and Georgia, by benefitting from zero or reduced tariffs for 3,500 products under the GSP agreement with the US (KPMG in Armenia, 2016), from a similar GSP agreement with Canada, Switzerland, Norway and Japan, and from GSP + contract with EU, which means zero or reduced import tariffs for 6400 products. On the other hand, both foreign investors and Armenia can benefit from the Free Economic Zone in Armenia, where there is no income tax, VAT tax, property tax or customs duties for companies operating in this area. The economic constraints and sanctions imposed on Russia and Iran by the US, the EU and several other countries have reduced the opportunities for cooperation between entities from these countries. Armenia is one of the EAEU member countries and has very good relations with Iran and can offer foreign entities access to these markets. So, those who plan to invest in Armenia have a chance to supply products or services to various parts of the world almost without restrictions. The government should inform foreign investors about all privileges in Armenia through all possible communication channels.

Then, it is necessary to stabilize the political and legal environment in Armenia. As exemplified by Poland, possible ways to improve the situation have already been shown. Political stability and the rule of law in Armenia will be a positive impulse not only for foreign entities but also for the Armenian diaspora, which has enormous financial possibilities. These funds have not been invested in Armenia so far due to a lack of confidence in the country's ability to guarantee the security of these funds.

In order to guarantee economic development, the Armenian government should constantly examine and control basic economic indicators such as inflation, unemployment, GDP growth, etc. Introduction of clever macro- and microeconomic policies will also be beneficial for the country. In order to make it attractive to foreign investors, Armenia needs to gain profits from its strengths (access to a huge international market, investment incentives and tax incentives for foreign entities, free economic zone, presence of international institutions and organizations, qualified, creative and well-educated employees, cheap workforce, considerable research and development opportunities in the fields of engineering, computer science, physics and mathematics, well-educated and talented workforce with technical skills and fluency in English, government support for strategic sectors, growing financial system) and develop the sectors of the economy that have the greatest potential for achieving success and attracting new 
investments (IT, agriculture, tourism, energy sector, mining and minerals, food industry, etc.). Tax policy for these sectors, which may have a strategic importance for the further development of the state, should also be reformed. All this will have a positive impact on the attractiveness of the country to foreign entities.

State investments in the health sphere, raising the level of education, solving demographic problems, increasing the expected length and quality of citizens' life as well as solving social problems will allow Armenia to build a satisfied, healthy and educated society. As a result, the inhabitants of this country will work better, and the quality of their work will be much higher. This will stop migration of qualified labor force, which will lead to economic growth, and investors from different parts of the world will be more interested in entering the Armenian market.

Armenia should continue to develop the new technologies sector. At present, the country offers various types of incentives for foreign IT companies (KPMG in Armenia, 2016). Armenia is a poor country in terms of natural resources, but it is not necessary to have this kind of resources to develop this sector. In the IT sector, the skills of employees and their education are the most important. Huge research and development opportunities in the fields of engineering, computer science, physics and mathematics, educated and talented workforce with technical skills, good university programs with specializations in computer science and related sciences, competitive labor costs and low operating costs, government support for the sector, sustainable and the continuous development of the IT sector and the presence of large global companies may attract foreign investors and persuade them to start operations in Armenia. The country's most important goal in this sector should be constantly improving the IT services provided and informing all interested foreign entities about the above-mentioned strengths.

Armenia's biggest weaknesses include the infrastructure problem. This is related to closed borders with Azerbaijan and Turkey. The development of infrastructure has key importance for the country, so now Armenia should use all possibilities to expand all possible ways of communication with the world. This will definitely cost a lot, but it is necessary for building a strong country.

The continuing war with Azerbaijan, historical problems with Turkey and general instability in the region have a negative impact on the attractiveness of Armenia. It seems that these problems cannot be resolved in the short term due to complicated relations between the countries but finding a mutually beneficial solution will have a positive impact not only on the attractiveness of Armenia but also on other countries of the region.

The educational reform, which has already been discussed, not only will increase the level of specialists but also make the majority of the population learn foreign languages. This will facilitate the communication process with potential foreign investors and improve cooperation with these entities.

Armenia, by carrying out various reforms and changes, should persuade foreign investors that, by investing in Armenia, they will have unlimited access to a very large market. If you consider the EAEU market, Georgia, Iran, USA, the EU and several other countries with no or reduced trade barriers, you can assess the potential market of Armenia as very large. All reforms are aimed at destroying all barriers and obstacles that may arise when a foreign investor wants to satisfy the needs of third-country markets by offering products and services produced in Armenia.

Summing up, the above-mentioned conclusions can be very beneficial for Armenia and its government because all the most important activities that can increase the country's attractiveness to foreign investors and lead to economic development are shown. 


\section{References}

Birnleitner, H. (2014). Attractiveness of countries for foreign direct investments from the macro-economic perspective. Proceedings of FIKUSZ '14 Symposium for Young Researchers (pp. 29-40). Óbuda University.

Central Statistical Office (Poland). (2017). Import \& Export of Poland. Retrieved from http://stat.gov.pl/en/ (30.08.2018).

Central Statistical Office (Poland). (2017). Unemployment rate in Poland. Retrieved from https://stat.gov.pl/obszarytematyczne/rynek-pracy/bezrobocie-rejestrowane/stopa-bezrobocia-rejestrowanego-w-latach-1990-2018,4,1. html (30.08.2018).

Country Economy. (2018). Global peace ranking. Retrieved from https://countryeconomy.com/demography/globalpeace-index (30.08.2018).

Czarny, E. (Ed.). (2005). Gospodarka Polska na przełomie wieków od A do Z. Narodowy Bank Polski.

Davies, A. (2004, June). The role of religion in the economy. International Journal on World Peace, 21(2), 37-42.

EF. (2018). 7th edition. English Proficiency Index. Retrieved from https://www.ef.pl/epi/regions/europe/poland/ (30.08.2018).

EY. (2017). Mature leader of the CEE region EY's attractiveness Survey. Retrieved from https://www.ey.com/ Publication/vwLUAssets/EY_Attractiveness_Survey_Poland_2017/\$FILE/EY-Attractiveness-SurveyPoland-2017.pdf (30.08.2018).

Gallup. (2009). Importance of religion by country. Retrieved from https://ipfs.io/ipfs/ QmXoypizjW3WknFiJnKLwHCnL72vedxjQkDDP1mXWo6uco/wiki/Importance_of_religion_by_country. html (30.08.2018).

Górecka, D. \& Szałucka, M. (2013). Country market selection in international expansion using multicriteria decision aiding methods. Multiple Criteria Decision Making, 8, 32-55.

Government of Poland. (n.d.). Rodzina 500 plus. Retrieved from https://pl.wikipedia.org/wiki/Rodzina_500_plus

Grant Thornton. (2017). Women in business New perspectives on risk and reward. International Business Report. grantthornton.global.

Inflation.eu. (2018). Historic inflation Poland - CPI inflation. Retrieved from https://www.inflation.eu/inflationrates/poland/historic-inflation/cpi-inflation-poland.aspx (30.08.2018).

Internet live stats. (2016). Internet users by country. Retrieved from http://www.internetlivestats.com/internet-usersby-country/ (30.08.2018).

Investopedia. (n.d.). Retrieved from https://www.investopedia.com/terms/f/foreign-investment.asp (30.08.2018).

ITSG Global. (2017, September 6). IT industry in Poland. Retrieved from http://itsg-global.com/it-industry-inpoland/ (30.08.2018).

Karasiewicz, G. \& Lemanowicz, M. (2005). Ocena atrakcyjności rynków zagranicznych przez małe i średnie przedsiębiorstwa. In Polski konsument i przedsiębiorstwo na jednolitym europejskim rynku (pp. 3-4).

Koch, A.J. (2001). Factors influencing market and entry mode selection: Developing the MEMS model. Marketing Intelligence \& Planning, 19(5), 351-361.

KPMG. (2018). Retrieved from Corporate tax rates table: https://home.kpmg.com/xx/en/home/services/tax/tax-toolsand-resources/tax-rates-online/corporate-tax-rates-table.html (30.08.2018).

KPMG in Armenia. (2016). Investment guide Armenia. kpmg.am. Retrieved from http://www.amcham.am/img/ Investment_guide_Armenia.pdf (30.08.2018).

McConnell, C., Brue, S., \& Flynn, S. (2011). Macroeconomics: Principles, problems, \& policies (18th ed.). McGraw Hill Education.

Moore Stephens Europe. (2017). Doing business in Poland 2017. Brussels. Retrieved from https://www. moorestephens.com/MediaLibsAndFiles/media/MooreStephens/Shared-Content/Shared-Publications/ Guides/Doing-business-in-Poland-2017.pdf?ext=.pdf (30.08.2018).

Rączaszek, A. (2012). Demograficzne uwarunkowania rozwoju gospodarczego. Katowice: Publishing House of the University of Economics in Katowice.

Russow, L. \& Okoroafo, S. (1996). On the way towards developing a global screening model. International Marketing Review, 13(1), 46-64.

The Global Economy. (2017). Political stability - Country rankings. Retrieved from https://www.theglobaleconomy. com/rankings/wb_political_stability/ (30.08.2018).

The Global Economy. (2017). FDI, percent of GDP - Country rankings. Retrieved from https://www. theglobaleconomy.com/rankings/Foreign_Direct_Investment/ (30.08.2018).

The World Bank. (2018). Population growth (annual \%). Retrieved from https://data.worldbank.org/indicator/ SP.POP.GROW? view=map (30.08.2018).

The World Bank. (2018). GINI index. Retrieved from https://data.worldbank.org/indicator/SI.POV.GINI?view=map (30.08.2018).

The World Bank. (2018). Ease of doing business index. Retrieved from https://data.worldbank.org/indicator/IC.BUS. EASE.XQ (30.08.2018). 
The World Bank. (2018). GDP growth (annual \%). Retrieved from https://data.worldbank.org/indicator/NY.GDP. MKTP.KD.ZG (30.08.2018).

The World Bank. (2018). GDP per capita (current US\$). Retrieved from https://data.worldbank.org/indicator/ NY.GDP.PCAP.CD?view=map (30.08.2018).

The World Bank. (2018). Logistics performance index. Retrieved from https://lpi.worldbank.org/international/global ?order=Infrastructure\&sort=asc (30.08.2018).

Trading Economics. (2018). Unemployment rate. Retrieved from https://tradingeconomics.com/country-list/ unemployment-rate (30.08.2018).

Trading Economics. (2018). Inflation rate. Retrieved from https://tradingeconomics.com/country-list/inflation-rate (30.08.2018).

Trading Economics. (2018). Poland GDP. Retrieved from https://tradingeconomics.com/poland/gdp (30.08.2018).

Transparency International. (2017, February 21). Corruption Perceptions Index 2017. Retrieved from https://www. transparency.org/news/feature/corruption_perceptions_index_2017 (30.08.2018).

United Nations Development Program (UNDP). (2016). Briefing note for countries on the 2016 Human Development Report-Poland.

United Nations Development Programme. (2018). Human Development Reports - Gender Inequality Index (GII). UN. Retrieved from http://hdr.undp.org/en/content/gender-inequality-index-gii (30.08.2018).

United Nations Development Programme. (2018). Human development reports (HDI values). UN. Retrieved from http://hdr.undp.org/en/countries (30.08.2018).

Worldometers. (2018). People living on Earth. Retrieved fromhttp://www.worldometers.info/watch/worldpopulation/ (30.05.2018). 